\title{
ENGLISH LANGUAGE TRAINING FOR PAKET C LEARNING PARTICIPANTS TO IMPROVE THEIR SPEAKING ABILITY
}

\author{
Nunu Mahmud Firdaus \\ IKIP Siliwangi \\ mahmudfirdaus@gmail.com
}

\begin{abstract}
The purpose of this study is to describe the process of tutoring, describe the results of learning English, and find out the effect of learning guidance on speaking skills of Paket C learning participants in PKBM (Society Learning Centre) Sukabaru. The research method used is descriptive qualitative through data triangulation. Data is collected using test techniques to obtain data about the results of English speaking skill of learning community before and after being given tutorial through trainings. The results of the study show that learning guidance influences the results of English learning in term of speaking skills. Through the training of English speaking, the participants show improvement in mastering English with indicators of mastering many English vocabularies, and being able to speak fluently. On English language training, the researcher conducts the observations on speaking English demonstration and the participants can apply speaking comprehension.
\end{abstract}

Keywords: Training, Speaking Skill, Paket C Learning Community

\section{INTRODUCTION}

\subsection{Background}

English language is one of the important subjects to be studied by learning participants of Paket C. English is taught in PKBM with a relatively less number of hours compared to the learning hours in school. English, for Paket C learning participants, is a skill with a high level of need. Because the learning participants to whom the writer is conducting the research are employees who work in medium-sized companies and small businesses, then the writer conducted the study of English language tutoring on speaking skills.

Based on the results of the study from March to May 2018 with the total of 10 participants studying at PKBM Sukabaru, Kecamatn Parongpong,
Kabupaten Bandung Barat, it can be concluded that the participants' English language ability is still low because they have not achieved the expected ability, that is to apply and implement habits of speaking language.

\subsection{Statement of Problems}

1. How is the participants' improvement of speaking English by conducting tutorial of speaking?

2. How is the participants' improvement of life skills and their ability to speak English?

\subsection{Research Objectives}

1.To find out the improvement of language skills of the learning community of PKBM Sukabaru.

2. To find new ways of providing language training to PKBM learning participants. 


\section{LITERATURE REVIEW}

At this stage, the researcher conducts literature reviews by studying reference books and similar research results. The aim is to get a theoretical basis for the problem to be examined. This theory is intended as a platform to understand the problems that are studied correctly and in accordance with scientific thinking framework.

\subsection{The Concept of Training}

One of the training missions is focused on the achievement of the organization. Working people usually get the skills from doing some training; they can analyze and overcome problems to work in organizations (Lynton, 1980).

Training produces repetitive actions that can lead to better self-motivation and change, and lead to forced actions that spur improvement towards mastering the problems or matters. Training is a teaching in the form of giving someone a chance to develop knowledge and skills in order to achieve something desired (Robinson 1981: 12).

\subsection{Speaking Ability}

Linguist said that "speaking is language". Speaking is a language skill that develops in a child's life, which is only preceded by listening skills, and at that time the ability to speak or say is learned. Speaking of course is closely related to the vocabulary development obtained by the child: through listening and reading activities. We also need to realize that the skills needed for effective speaking activities are similar to those needed for effective communication in other language skills (Marzuki, 2010).

Humans are social creatures and the most important first action is social action, an act of exchanging experiences, expressing and accepting thoughts, expressing mutual feelings, and agreeing to a position or belief. Therefore, in social action there must be general elements; in addition, creating and preserving ties of public interest, creating a unity of symbols that distinguishes it from other groups, and establishes an action. Therefore, this will not happen and will not last long without the language community. In other words: society is in linguistic communication.

Speech as a way of communicating greatly affects our individual lives. In this system we exchange opinions, ideas, feelings, and desires, with symbols called words. This system provides effectiveness for individuals in establishing mental and emotional relationships with other members. Presumably there is no doubt that utterance is merely an expression of one's personal ideas, and emphasizes twoway, giving and receiving relationships (Powers, 1954: 5-6).

\section{RESEARCH METHODS}

This study uses a qualitative method to see a clear picture of the results of the training of speaking conducted to 10 learning participants PKBM Sukabaru. In data analysis, the researcher uses a formula that matched the areas of ability to be classified so that the right results can be obtained to answer the problem formulation and assumptions that had been made. Some data analysis techniques used in this study includes conducting interviews to make questionnaires to the results of the training carried out.

This research method in the study uses qualitative methods. This is based on the consideration of the depth of the research results that relate to the meaning of generalization, so that the researcher will maximize the research strengths in terms of observations and interviews, both in regards with the relevance of the content of the question with the study, and related to the accuracy of the respondents.

At this stage the researcher conducts a study of the problem with the initial observation of the field to observe the problems relevant to the study of English 
Language Training on Paket C Learning participants in improving their Speaking Ability.

\section{ANALYSIS AND DISCUSSION}

In the analysis, on the factors that influence the participants' mastery of English from the results of interviews done by the researcher to the respondents, it is found that improvement in English language skills in this study is the ability to speak English. Strong influences in improving these skills in addition to intelligence there are also other indicators; namely, the ability of the coach or tutor in developing the interests and talents of the learning participants to have courage in expressing language. Respondents are given a guide in the form of dictionaries to add vocabulary. Tutor in this case is the researcher providing understanding of form-time in English, such as to be and capital auxiliary. After giving understanding, the researcher tries to instruct the participants to perform demonstrations several times over and over.

On other indicators the researcher also sorts out the interests and talents to prove their assumptions. English language training at PKBM Sukabaru can provide satisfying results for the participants in terms of their speaking ability. They can also practice habituation in using English so that they are not rigid in using English but are more enthusiastic to conduct further training.

In this study, the researcher conducts interviews with the respondent which brings positive results for the ten participants claiming that there is more experience obtained from the English language training, and respondents said that from the training they already have acquired language skills and life skills as well.

\section{CONCLUSIONS \& SUGGESTIONS}

\subsection{Conclusion}

1. Conclusions that can be drawn from the discussion are that English language training can improve abilities, especially speaking by doing several repetitions of conversation demonstrations.

2. By conducting training with the repetition of the demonstration, the participants are encouraged to know the language structure that must be expressed; thus, there is an understanding of more difficult material,

\subsection{Suggestion}

1. The participants of PKBM Sukabaru should attend additional training which does not only rely on learning in PKBM which is still less intensive in conducting English training.

2. This training strategy is an old method but still has implications for the expected competencies; besides providing new strategies from other researchers' research on the effectiveness of training techniques

\section{DAFTAR PUSTAKA}

Faisal, Sanapiah, Penelitian Kualitatif dan aplikasi, YA3, Malang, 1990.

Lynton, R.P 1980 Training for Development.Illionis; Richard D. Iirwin Inc.

Marzuki, Saleh 2010 Pendidikan Nonformal. PT Remaja Rosdakarya. Powers, David Guy 1951, Fundamental of Speech New York: Mc Graw-Hill Book Company, Inc.

Turagan Henry 2018 Berbicara sebagai kemampuan berbahasa, Angkasa Bandung 